\title{
Mathematics in Home Economics Skills Acquisition for Socio- Economic Transformation in Nigeria: Implications for Extension Delivery.
}

\author{
Adah, Obe Christopher, $\mathrm{PhD}^{1}$, Ogbadu, R.A. ${ }^{2}$, Haruna, G.G. ${ }^{3}$, Yusufu, Stephen A.O. ${ }^{3}$,
} Enemali, I.A. ${ }^{3}$

1. Department of Agricultural Economics and Extension, Kogi State University, Anyigba, Nigeria 2. Department of Home Economics, 3. Department of Mathematics,

Kogi State College of Education, Ankpa;

In Affiliation with;

Abstract

Abubakar Tafawa Balewa University, Bauchi, Nigeria.

Mathematics is said to be the life wire or mother of science and technology; and other disciplines. It contributes immensely in deciding directions of activities in all areas of human endeavours such as economy and training etc. At present, Nigeria is experiencing series of economic quagmire of which skills-oriented programme such as home economics skills acquisition could help tackle. On this premise, the paper focuses on the concepts of mathematics, skills acquisition in home economics, socio-economic transformation, philosophy and objectives of home economics as well as contributions of mathematics to the acquisition of some home economics skills. Implications for extension are also x-rayed. To realize the desired socio-economic transformation of the country, it has been suggested that both skilled and unskilled business operators in home economics should be assisted to enhance their production level to enable them employ other Nigerian citizens through a wellfunded extension programme.

Keywords: Mathematics, Home Economics, Skills, Transformation, Extension.

DOI: $10.7176 / \mathrm{MTM} / 9-8-04$

Publication date: August 31st 2019

\section{Introduction}

The relevance as well as significance of education as a veritable tool for national transformation cannot be overstressed. According to Okoye (2005) mathematics is one of the key and indispensable basic elements in the educational system and if only it is taught effectively in schools, it can be a weapon for realizing the national goals of education in Nigeria.

Mathematics according to Fadare and Ayeni (2016) is viewed as a service provider for all disciplines and that it contributes immensely in deciding directions of activities in all areas of human endeavours such as economy, banking, and market transactions etc. In the same vein, Usman (2002) pointed out that the subject has been described as the life wire of 
disciplines. This is because it is applicable in science, technology, arts, commerce and politics among others (Abakpa, Agbo-Egwu and Takor, 2014).

Supporting the above position, Odili and Imoko in Fadare and Ayeni (2016) concluded that mathematics is an essential tool for the advancement of science and technology in the present era and neglecting it would affect national development negatively, thus any government that puts aside mathematics and its application will not be too far from zero level.

Still highlighting on the importance of the subject, Gbadeyan (2015) stated that mathematics is considered to be wearing two caps. First, it is the queen of all sciences as it plays a significant role in the development of science and technology and hence in the development of any nation, as no nation can be said to have developed without developing scientifically and technologically. Second, it is the king of all other subjects, the reason for rating it core at all levels of our education in Nigeria. Mathematics is a creative discipline and its language is international; and that it transcends cultural boundaries and its importance is universally recognized, hence it cannot be considered as a classroom discipline only (Fadare and Ayeni, 2016).

At present, Nigeria is passing through a very difficult economic situation in all spheres of life including the inability of majority of her citizenry to afford adequate food for their households. This state of affair requires great attention. Embracing skill-oriented education programme such as home economics becomes imperative. This is because in home economics, a lot of skills capable of empowering many unemployed Nigerians are taught to youths and other interested members of the society, to help address unemployment problem and poor economic situation currently being experienced in the country. It is on this premise, therefore that the paper focuses on the concepts of mathematics, home economics skills acquisition for the realization of socio-economic transformation in Nigeria. Implications for extension delivery are also x-rayed. 


\section{The Concept of Mathematics}

Mathematics is defined by Aristotle as the science of quantity; and that classification of sciences, discreet quantities were studied by arithmetic, continuous quantities by geometry (Harisu, 2016). Also, encyclopedia Britanica (2008) in Harisu (2016) defined mathematics as the science of structure, order, and relation that has evolved from counting, measuring and describing the shape of object. It deals with logical reasoning.

Oxford dictionary - online in Gbadeyan (2015) looks at mathematics as the abstract science of number, quantity, and space, either as abstract concepts (pure mathematics) or as applied to other disciplines such as physics and engineering (applied mathematics). In contemporary education, mathematics education is the practice of teaching and learning mathematics along with the associated scholarly research (Wikipedia Free Encyclopedia, 2014, and Gbadeyan, 2015).

Anthony and Walshaw (2014) in Enemali and Adah (2015) pointed out that mathematics is the international of all curriculum subjects and mathematical understanding influences decision making in all areas of life-private, social and civil. It is key to many spheres of life including its application in home economics skills acquisition.

Mathematics is the study of numbers and how they are related to each other and to real world (Kogi State College of Education, Ankpa (KSCOEA), 2012); as seen in its everyday usage in telling time, playing games and doing almost any kind of work. In line with this, Onoja (1999) described mathematics as a creation of the human mind, concerned primarily with ideas, processes, and reasoning which makes it useful in the solution of all kinds of problems in the science, government, and industry; and by extension, skills acquisition in home economics.

Mathematics, as a tool for understanding and application of science and technology, plays an important role of a precursor and harbinger to the much needed technological and of 
course national development, which has become an imperative in the developing nations of the world (Ajai and Imoko, 2011 in Adah and Enemali, 2016). The significance of mathematics as the life wire of disciplines therefore stands out very clearly. Hence, its application to skills acquisition in home economics is also imperative.

The main goal of teaching mathematics according to Abakpa, Agbo-Egwu and Takor (2014) is that it is a vehicle for training the child to think, reasons, analyses and articulates logically. According to Abakpa and Iji (2012) in Adah, Enemali and Negedu (2016) mathematics skills include:

i) understanding mathematical concepts and techniques of computation;

ii) skills in using these understanding skills in computation; and

iii) skills in thinking creatively.

From the foregoing, skills acquisition in home economics encompasses all forms of measurement, calculation, weighing, computation, record and account keeping etc in various occupational areas in home economics such as clothing and textiles, food and nutrition and home management. For these to be realized, modern skills acquisition in home economics via sound mathematical knowledge is very imperative.

\section{The Concept of Skills Acquisition in Home Economics}

Skills acquisition is a specific form of learning (Adah et al. 2016). Home economics is a field of study that deals with many things; the most important concern of it is the welfare of individuals, families and society (Anyakoha (2000). Fayemi et al. (1981) in Odo (2005) defined it generally as the appreciation of many sciences and arts towards the achievements of a healthy and happy home.

Home economics is a non-agricultural extension programme/endeavour that aims at helping learners to live well by depending and utilizing practical skills on general home making (Ahiakwo in Adesope, 2007). Learning as we know is supposed to eventually fit 
individuals in this area into endeavours that are useful for home making. In the process the individuals can take proper care of their homes and by extension, the community. Ahiakwo in Adesope (2007) stressed that home economics in its entirety focuses on individual development, family living and a meaningful interpersonal relationship of mankind. It is concerned with the well being of the family therefore seeking ways of providing reasonable solutions to family problem. It is also a field of knowledge that provides services that are directed towards strengthening family life.

According to Longman Advanced Dictionary (2009) skill is an ability to do something well, especially because you have learned and practiced it, while acquisition is the process by which you gain knowledge or learn a skill. Also, skill is the ability to perform manual, technical or operational activities using accumulated knowledge or experience (Kogi State University, 2015).

Home economics skills acquisition therefore is the process or ability to perform well manual or technical activities in clothing and textiles, food and nutrition, home management and nursery management. Hence, Osuala (1980) in Onuekwe (2005) stated that the following businesses are established from home economics:

i. $\quad$ Nursery school.

ii. Clothing management, production and services, fashion designers, sewing, tie and dye, weaving, etc.

iii. Food management production and services e.g. restaurant or hotel.

iv. Home furnishing, equipment and services.

\section{The Concept of Socio-economic Transformation}

Adah and Onoja (2005) in Adah et al. (2016) refer to social as an attributive term concerning the organization of and relations between people and communities, while economic is an attributive term relating to trade, industry and the development of wealth or 
anything profitable. Transformation according to Longman Advanced Dictionary (2009) is a complete change in someone or something.

Socio-economic transformation would therefore mean a complete change in the ways people and communities (society) behave profitably in terms of trade, industry and development of wealth or anything worthwhile. Today in Nigeria, there are several socioeconomic problems such as unemployment, inflation, insecurity, kidnapping, armed robbery, oil pipeline vandalisation culminating into depressed economic situation, youth restiveness, cultism, among others. Home economics skills acquisition is therefore imperative to these current socio-economic realities in our lives as a Nigerian people.

\section{Philosophy and Objectives of Home Economics}

A treatment of philosophy and objectives of home economics would enable us to Properly appreciate the field as skill-oriented type; hence the acquisition of such skills goes a long way to benefitting the society. According to Ahiakwo in Adesope (2007) the philosophy and objectives of home economics include:

i. enhancing competence through education for effective family living;

ii. enabling students to learn skills that will help them to do their roles most satisfactorily;

iii. inculcating values worthy to stand the test of time in any situation or circumstances;

iv. applying modern science to improve individual and family living relating to the basic area of home economics; and

v. using knowledge acquired from the other fields and research findings to improve the laws of making through the family.

Home economics provides knowledge for home makers. As home makers, home economists produce goods (materials, foods, textiles etc) and services (catering etc) for people 
and the society. They also make valuable decisions in terms of nutrition; clothing and general home management.

Ahiakwo in Adesope (2007) stated that home economics is concerned with the wide range of activities dealing with home and family life. She pointed out that the women have always been the focus of home economics because they are very important catalysts of change in the home; they are the ones responsible for home making as they are consumers as well as producers whose activities include:

a. caring for and training children;

b. producing; preserving and preparing food for the family;

c. improving the sanitary and physical environment of the home to protect the health and well-being of the family members;

d. selecting, making, carrying for clothing and articles of household use;

e. managing all available resources including those provided through community services; and

f. managing and improving the home (Ahiakwo in Adesope, 2007).

A cursory look at the above activities of women/operators of home economics demands that skills acquisition by them is worthwhile. In this direction, mathematics is a veritable instrument for the realization of the goal.

\section{Contributions of Mathematics to the Acquisition of Some Home Economics Skills.}

Ajai and Imoko (2011) in Adah et al. (2016) pointed out that the contributions of mathematical knowledge and skills have made to economic, industrial, and technological growth of modern world are quite obvious to almost everyone. In many ways mathematical applications can enhance home economics skills acquisition. This is reflected in the use of modern technology for many varied operational activities in home economics. Business technology in home economics had brought many changes in the manufacturing, advertising 
and marketing of goods and services (Onuekwe, 2005). For example, Latham (1992) in Onuekwe (2005) stated that the new technology led to the use of the following:

a. new machines e.g. automated stitches machine;

b. new products e.g. sugar - free snacks;

c. new types of jobs e.g. computer operators;

d. new materials e.g. non-sticky coatings; and

e. new production methods e.g. computer programming.

In addition to the above, Latham in Onuekwe (2005) stated also that due to advancement in mathematics which culminated into modern technology, new automated production methods have been introduced and these:

a. reduce the amount of labour needed,

b. increase efficiency and productivity;

c. reduce costs;

d. make production quicker;

e. increase the amount of products; and

f. produce standard quality.

In specific terms, mathematical applications in skills acquisition in home economics are in the areas of numeration, measurements, weighing, time and computer programming. In food and nutrition a lot of measurements are done. For example, automated production in the manufacture of biscuits. According to Onuekwe (2005), the quantity of ingredients are measured and/controlled by computer programme; after mixing the ingredients by machine, the pastry cutter which is also a giant machine, cuts the biscuits, then the conveyor belt passes the cut biscuits into oven. All the stages in the production of biscuits are being performed by machines including the weighing, wrapping, packaging and sending them to warehouses. 
Many snacks manufacture also pass through automated production method. Such snacks include: dough nut, meat/fish pie, short-bread, sausage roll etc.

Apart from using automated method of production, manual method could be embraced in manufacturing snacks. Some Nigerian native snacks manually manufactured using mathematical applications are; Kokoro (corn biscuit), gurundi (coconut and cassava starch biscuits), groundnut cake/biscuit and akara. Two practical examples of how these snacks are done using mathematical knowledge are shown below (Oseni, 2011):

i) Kokoro (Corn Biscuit):

2 cups of parboiled dry corn

$1 / 2$ medium ground onion

2 cups of vegetable oil

1 egg (optional)

Dry pepper and salt to taste.

ii) Groundnut Cake/Biscuit:

2 cups of groundnuts

$1 / 2$ teaspoon of dry pepper

Salt to taste

$1 / 2$ cup of boiling water

Groundnut oil

In these two examples, all the ingredients could be seen with measurements. They could be made into desired shapes ranging from rectangular, round, star to filamentous shape. Specific timings are employed.

Oseni (2011) also pointed out that a wide variety of interesting dishes can be prepared using rice as the main ingredient and they include jollof rice, coconut rice, boiled rice, and kedgeree. The ingredients of these dishes are well measured to specifications. For instance, 
jollof rice that could serve four persons would have the following measurement of ingredients:

Jollof Rice:

2 cups $(450 \mathrm{~g})$ of rice

6 large peppers (ground)

4 small peppers (ground)

4 tomatoes (ground)

1 small onion

2 tablespoons of oil

1 small tin or 1 dessertspoon tomato puree

$500 \mathrm{~g}$ meat

6-8 cups of water

Salt, pepper and thyme to taste.

Clothing and textile is another area in home economics requiring a lot of acquired skills. To embark on any production in clothing and textile, various stages and kinds of measurement are required. Apart from manual production method which also requires a lot of skills, modern machines are also employed. Productions in clothing and textiles are majorly in tie-dyeing and batiking; laundry and dry cleaning; wedding garments, toys and gifts; embroidery, knitting and crocheting; fabric repairs, bed sheet and bed cover production; pattern making; and the business of these products (Ogbadu, 2009).

In all these, skills in buying and selling, account keeping, sales record, materials procurement records etc are imperative. Numbering of clothing materials during production is also very important. Using computer for designing and accessing different and latest clothing patterns on the net is also required. 
In home management, skills acquisition via sound mathematical knowledge or applications abound. Take functional areas in the home for instance. It requires acquiring mathematical knowledge and skills to know the capacity of the sitting room, the number of furniture suitable for the room, the curtains and decoratives including the colour. In room arrangement Oseni (2011) pointed out items which can be used as accessories to create the centre of interest and they include:

i. Wall hangings on the walls of sitting rooms, dining rooms and bedrooms.

ii. Flower arrangements may be placed in room corners to produce staking effect.

iii. Ornaments may be placed on table tops, dressing tables and side tables.

iv. Potted plants can improve the appearance of living rooms and balconies.

v. Hand-rest or scatter-cushions can be placed on beds and sofas.

To achieve all these in the home requires a lot of mathematical calculations; measurements are involved consciously or otherwise.

Linear programming, an aspect of mathematics can be used in home economics skills acquisition. Various home economics operators need to consider all aspects of their professional operations in order to be successful in their ventures. Operators of restaurants create mathematical systems of equations and inequalities to help them make decision about which dishes to prepare in which particular periods or times of the year, a system of organization commonly referred to as linear programming.

Gardening, horticulture, livestock (poultry, goats etc) rearing are veritable components in home economics and knowledge and skills of mathematics are needed for their profitable husbandry. Hence, Amodu et al. in Enemali and Adah (2016) pointed out that mathematics are utilized in the following areas of farming to reduce or alleviate poverty and unemployment currently endemic in Nigeria:

i) basic skills in simple mathematical calculations in agriculture; 
ii) counting and recording skills in agriculture;

iii) a poultry farmer needs to know the number of eggs his/her birds lay per day;

iv) right spacing which improves crop growth and yield; and

v) knowledge of basic measurement skills necessary in oral drug administration in livestock farming.

According to Togun et al. (2007) in Adah and Enemali (2016) mathematics knowledge and skills are employed in agribusiness, and by extension home economics ventures; to effectively keep production records, salaries and wages account (if any), sales record, cash receipts and petty cash voucher, correspondence records, bank statement, cash book purchase order, debtors/creditors record, monthly financial summary and casual workers record. These are very significant especially in home economics ventures that are large. Examples include: fashion and designer's shopping centres, classical restaurants, child care and development centres etc.

\section{Implications for Extension Delivery}

Extension education according to Williams (1978) in Ogunbameru, Undiandeye, Ukwapu and Ani (2008) is an out-of-school voluntary adult education programme, using teaching and learning principles, concerning peoples' livelihood, carried out in a systematic way in an atmosphere of mutual trust and respect. The term "voluntary" is used because the people (clientele) are not under compulsion to use what they are taught; they only need to be motivated. According to Ogunbameru et al. (2008) it is an "out-of-school" because it does not involve a classroom exercise; it is taken to the clientele in their homes or farms. It uses teaching and learning principles because different techniques are adopted to teach the people depending on their unique situations and availability of teaching materials. People's livelihood is the concern of extension, otherwise the people may not like to key into it. Finally, there must be mutual respect between the extension agents and the clientele. 
In the light of the above and for the realization of the desired home economics skills acquisition; the extension practitioners through study and outreach programmes should evolve pragmatic approaches for the dissemination of modern and improved technologies which might be beneficial to operators of home economics skills-oriented ventures. Several skills are copiously available in home economics for different categories of operators, whether professional or informally trained under the auspices of apprenticeship principle to explore for gainful livelihood. It behooves the extension agents to study and know the felt needs of each category of the operators of home economics ventures, to enable them know how to come into their assistance for greater performance and productivity which at the end of the day goes a long way to raising the standard of living of such operators.

Success of any extension work depends on thorough training of the extension workers and local leaders. The extension staff should therefore be soundly trained to be able to cope with the latest research findings and technologies from various research stations and institutes aimed at developing agriculture (Adah, Enemali, Adejoh \& Edoka, 2015) and skills-oriented programmes like home economics. The issue at stake is home economics skills acquisition is aimed at reducing unemployment and to transform Nigeria socio-economically. Extension sub-programme of the relevant government agencies should therefore be up and doing to ensure realization of the country's desired goal of socio-economic transformation.

\section{Conclusion}

Mathematics is key to development generally. It is also said to be the service provider or life wire of disciplines. Its contributions to home economics skills acquisition has been addressed by the paper. Efforts should therefore be put in place to ensure that those operating business ventures in home economics, whether skilled or unskilled, should be assisted to enhance their production level, to enable them employ other citizens as a way of transforming the country. This is a herculean task for extension. To this end, extension delivery should be 
both participatory and democratic in approach. Further to this adequate funding of extension

component of the relevant government agencies should be taken seriously and sustained to

ensure sustainable national transformation in Nigeria.

\section{References}

Abakpa, B.O., Agbo-Egwu, A.O. \& Takor, D.I. (2014), Challenges perceived by mathematics teachers as militating against teaching mathematics for creativity in primary school pupils: A way forward. African Journal of Arts, Sciences and Educational Issues (AJASE I). 2(2) 30-37.

Adah, O.C. \& Enemali, I.A. (2016), Mathematics for agricultural entrepreneurship in Nigeria. In Sadiku, J.S. (ed.), Proceedings of September, 2016 Annual National Conference of Mathematical Association of Nigeria (M.A.N).433-437.

Adah, O.C., Enemali, I.A., Adejoh, S.O. \& Edoka, M.H. (2015), Mathematics applications for agricultural development: Implications for agricultural extension delivery. Journal of National Science Research. 5(20) 112-118.

Adah, O.C., Enemali, I.A. \& Negedu, T.O. (2016), The role of mathematics education in farming skills acquisition for social and economic transformation in Nigeria. Being a paper presented at the $3^{\text {rd }}$ Annual National Conference of Forum of Academics for Educational Advancement and Initiative in Nigeria (FAFEAIN) held at Federal College of Education, Okene, Kogi State. $13^{\text {th }}-17^{\text {th }}$ June.

Adesope, O.M. (2007), Agricultural youth organizations: Introductory concepts. Second edition. Port Harcourt, University of Port Harcourt Press. 93-98.

Anyakoha, E.U. (2000), Home economics for junior secondary school. Onitsha, Africana Fep Publishers.

Enemali, I.A. \& Adah, O.C. (2015), Empowering individuals and communities through agricultural education: The role of mathematics education. Journal of Vocational and Technical Educators. 4 (4) 46-50.

Enemali, I.A. \& Adah, O.C. (2016), Mathematics as an instrument for poverty alleviation on the farm in Nigeria. In Sadiku, J.S. (ed.). Proceedings of September, 2016 Annual National Conference of Mathematical Association of Nigeria (M.A.N). 428-432.

Fadare, A.O. \& Ayeni, A.A. (2016), The role of mathematics in enhancing good governance. In Sadiku, J.S. (ed.), Proceedings of September, 2016 Annual National Conference of Mathematical Association of Nigeria (M.A.N).397-407.

Gbadeyan, J.A. (2015), Mathematics education for employment generation and sustainability. In Sadiku, J.S. (ed.), Proceedings of September, 2015 Annual National Conference of Mathematical Association of Nigeria (M.A.N). 1-15

Harisu, A. (2016), Mathematics: A veritable tool for poverty alleviation. In Sadiku, J.S. (ed.), Proceedings of September, 2015 Annual National Conference of Mathematical Association of Nigeria (M.A.N).354358.

Kogi State College of Education, Ankpa (2012), Mathematics in a nutshell. KSCOEA Newslink_2(1) 8.

Kogi State University (2015), Entrepreneurial university skills harmonised EDS 202 and 302 module. Anyigba, Entrepreneural Skills Development Centre, Kogi State University. 15.

Longman Advanced Dictionary (2009), Longman advanced dictionary of contemporary English New edition. Essex, Pearson Education Limited.

Odo, E.N. (2005), Forms of home economics business ownership. In Ezema, P.N., Paul, E.O., Anioke, B.O., Okwuolise, G.A.G., Eheli, C.A. \& Anih, H.U. (eds.), Entrepreneurship in vocational education volume 1.Enugu, Modern Printers (Nig.).268-276.

Ogbadu, R.A. (2009), Clothing and textiles occupations and poverty alleviation for improved standard of living. In Daluba, N.E. (ed.), Vocational and technical education and the attainment of national educational goals. Kaduna, Euneeks\& Associates.24-32.

Ogunbameru, B.O., Undiandeye, U.C. and Ani, A.O. (2008), Definitions, philopshy and principles of agricultural extension. In Ogunbameru, B.O., Undiandeye, U.C. \& Ani, A.O. (eds), Agricultural extension methodologies. Kaduna, Apani Publications \& Ibadan, Louds Books (Publishers).1-12.

Okoye, F.N. (2005), Need to use information and communication technology (ICT) in teaching and learning mathematics in Nigerian secondary schools for self-actualization and sustainable development. The Nigerian Journal of Curriculum and Instruction. 13 (1) 84-88.

Onoja, F.A. (1999), Translating some economics theories into mathematical relations. Ankpa Journal of Arts and Social Sciences (AJASS). 1(1) 18-22. 
Onuekwe, M.E. (2005), Home economics business and technology: Issues and problems. In Ezema, P.N., Paul, E.O., Anioke, B.O., Okuolie, G.A.G., Eheli, C.A. \& Anih, H.U. (eds), Entrepreneurship in vocational education volume 1.Enugu, Modern Printers (Nig.).301-306.

Oseni, D.O. (2011), Basic home economics for junior secondary schools 2. UBE edition.Ikeja, Longman Nigeria Plc.

Usman, K.O. (2002), The need to retrain in-service teachers for the attainment of universal basic education. Journal of the Mathematical Association of Nigeria.375.

Wikipedia Free Encyclopedia (2014), Concept of Mathematics Education. http://en.m.wikipedia.org/wiki. Accessed on 04/09/14. 